University of Nebraska - Lincoln DigitalCommons@University of Nebraska - Lincoln

USGS Staff -- Published Research

US Geological Survey

2015

Estimating Relative Sea-Level Rise and Submergence Potential at a Coastal Wetland

Donald R. Cahoon

U.S. Geological Survey, dcahoon@usgs.gov

Follow this and additional works at: http:// digitalcommons.unl.edu/usgsstaffpub

Part of the Geology Commons, Oceanography and Atmospheric Sciences and Meteorology Commons, Other Earth Sciences Commons, and the Other Environmental Sciences Commons

Cahoon, Donald R., "Estimating Relative Sea-Level Rise and Submergence Potential at a Coastal Wetland" (2015). USGS Staff -Published Research. 992.

http:// digitalcommons.unl.edu/usgsstaffpub/992

This Article is brought to you for free and open access by the US Geological Survey at DigitalCommons@University of Nebraska - Lincoln. It has been accepted for inclusion in USGS Staff -- Published Research by an authorized administrator of DigitalCommons@University of Nebraska - Lincoln. 


\title{
Estimating Relative Sea-Level Rise and Submergence Potential at a Coastal Wetland
}

\author{
Donald R. Cahoon
}

Received: 19 February 2014 / Revised: 22 July 2014 / Accepted: 14 August 2014 / Published online: 5 September 2014

(C) Coastal and Estuarine Research Federation (outside the USA) 2014

\begin{abstract}
A tide gauge records a combined signal of the vertical change (positive or negative) in the level of both the sea and the land to which the gauge is affixed; or relative sealevel change, which is typically referred to as relative sea-level rise (RSLR). Complicating this situation, coastal wetlands exhibit dynamic surface elevation change (both positive and negative), as revealed by surface elevation table (SET) measurements, that is not recorded at tide gauges. Because the usefulness of RSLR is in the ability to tie the change in sea level to the local topography, it is important that RSLR be calculated at a wetland that reflects these local dynamic surface elevation changes in order to better estimate wetland submergence potential. A rationale is described for calculating wetland RSLR (RSLR ${ }_{\text {wet }}$ ) by subtracting the SET wetland elevation change from the tide gauge RSLR. The calculation is possible because the SET and tide gauge independently measure vertical land motion in different portions of the substrate. For 89 wetlands where RSLR $_{\text {wet }}$ was evaluated, wetland elevation change differed significantly from zero for $80 \%$ of them, indicating that RSLR $\mathrm{wet}_{\text {wet }}$ at these wetlands differed from the local tide gauge RSLR. When compared to tide gauge RSLR, about $39 \%$ of wetlands experienced an elevation rate surplus and $58 \%$ an elevation rate deficit (i.e., sea level becoming lower and higher, respectively, relative to the wetland surface). These proportions were consistent across
\end{abstract}

Communicated by Carolyn A. Currin

Electronic supplementary material The online version of this article (doi:10.1007/s12237-014-9872-8) contains supplementary material, which is available to authorized users.

D. R. Cahoon $(\bowtie)$

US Geological Survey, Patuxent Wildlife Research Center, 10300 Baltimore Avenue, c/o BARC-East, Building 308, Beltsville, MD 20705, USA

e-mail: dcahoon@usgs.gov saltmarsh, mangrove, and freshwater wetland types. Comparison of wetland elevation change and RSLR is confounded by high levels of temporal and spatial variability, and would be improved by co-locating tide gauge and SET stations near each other and obtaining longterm records for both.

Keywords Relative sea-level rise - Wetland elevation - Tide gauge $\cdot$ SET $\cdot$ Vertical accretion $\cdot$ Shallow subsidence . Shallow expansion

\section{Introduction}

Determining the potential for wetland submergence by rising sea levels is an issue of critical importance to coastal resource managers that requires knowledge of local changes in sea level and wetland elevation. For nearly two centuries, highresolution trends $(\mathrm{mm} / \mathrm{y})$ of relative sea-level change have been derived from long-term tide gauge records (IOC 2006). Because a tide gauge is affixed to the crust of the Earth, and that crust may have its own vertical motion, it is impossible to use the tide gauge record by itself to separate out the absolute sea-level rise signal from the absolute vertical land motion (VLM) signal. Thus, this combined signal recorded at a tide gauge reflects relative sea-level change; or what is typically referred to as relative sea-level rise (RSLR). Yet, it is highly unlikely that RSLR measured in upland or built environments (e.g., the upland bench mark is attached to a building) at a tide gauge station fully represents the RSLR occurring at nearby wetlands. This is because coastal wetlands are typically located some distance from a tide gauge and its upland bench marks, often in different hydrologic and geologic settings. In addition, global evaluations of wetland elevation trends using the high resolution $(\mathrm{mm} / \mathrm{y})$ surface elevation table-marker horizon (SET-MH) method (Cahoon et al. 1995) reveal that 
wetland elevation trends vary within and among wetlands, ranging from positive to negative slopes influenced by both surface vertical accretion and erosion, and subsurface subsidence and expansion processes (Cahoon et al. 1999, 2006). The SET-MH method is currently used in 29 countries on six continents in both temperate and tropical coastal regions to evaluate elevation dynamics in primarily salt marsh and mangrove environments (Webb et al. 2013). Unlike the upland habitats where tide gauges are located, salt marshes and mangrove forests are able to alter their surface elevation by trapping sediments brought in by the tide, and through belowground production and accumulation of roots and rhizomes. In addition, these soft, unconsolidated sediments are subject to compaction and shrink-swell processes to a greater extent than upland soils. Therefore, although RSLR as recorded by a tide gauge provides an accurate estimate of the relationship between local uplands and sea level, it does not provide an accurate estimate of the relationship between local wetlands and sea level. In order to determine wetland submergence potential as sea level rises, one must consider surface elevation change in the wetland along with RSLR measured by the tide gauge.

This paper provides a brief review, from a methodological perspective, of the approaches used to estimate RSLR by sea level scientists and wetland elevation change by coastal wetland scientists, in order to determine wetland submergence potential. The motivation behind this paper is to clarify how measures of RSLR by a tide gauge and wetland surface elevation change by a SET are independent and complementary, how the two datasets are used together to estimate local sea-level rise at a wetland site, and to propose a standard approach and terminology for quantifying and describing wetland vulnerability to sea-level rise. Accounting for wetland surface elevation change in conjunction with tide gauge measures of RSLR allows for a direct calculation of wetland elevation rate deficit or surplus relative to sealevel rise (Cahoon et al. 1995), for which the proposed new term is wetland RSLR ( $\left.\operatorname{RSLR}_{\text {wet }}\right)$. The importance of calculating $\mathrm{RSLR}_{\text {wet }}$ is demonstrated from a literature review of the magnitude and direction of wetland elevation change measured with the SET device. Furthermore, terms such as shallow and deep subsidence used by the SET-MH community (Cahoon et al. 1995), and how these processes are measured, are clearly defined in the context of the long-established vocabulary for subsidence used by the tide gauge community. Lastly, the influence of high temporal and spatial variability in both the wetland elevation and sea level trends on interpreting wetland submergence potential is described, as is the need for co-locating SET and tide gauge stations whenever practical, and obtaining long-term records of both.

\section{Complementarity of RSLR and Wetland Elevation Change Measures}

\section{Tide Gauge RSLR}

A tide gauge measures sea level in relation to a primary reference point on land represented by a bench mark located on a stable surface such as exposed rock or a stainless steel rod driven to refusal, ideally to bedrock (Baker 1993; Bevis et al. 2002; IOC 2006). Typically a network of $5-10$ bench marks is established in the vicinity of each tide gauge, often at different depths in the substrate, and the most stable bench mark is designated the tide gauge bench mark (TGBM) or primary reference point for sea level observations (Fig. 1). The primary bench mark is connected to the tide gauge at its contact (sensor "0") point by high-precision leveling repeated annually to determine vertical stability of the gauge (IOC 2006), relative to the surrounding bench marks. All bench marks in the network are also connected to each other by high-precision leveling repeated annually. Thus, a tide gauge records a relative sea-level rise because it measures sea level change relative to the bench marks attached to the crust, which is in motion. The crustal VLM, or $\mathrm{VLM}_{c}$, portion of the RSLR trend is the velocity of the substratum at the base of the TGBM (Fig. 1).

\section{Wetland Elevation Change}

Nearly 50 years ago, Kaye and Barghoorn (1964) described quantitatively the autocompaction of marsh soils that results in a change in level of the marsh surface. The implications of their findings are twofold. First, for a coastal marsh to maintain a constant elevation, the accumulation rate of mineral and organic material on or near the marsh surface must equal both the rate of crustal motion occurring below the marsh substrate as measured at a tide gauge, plus the rate of autocompaction (i.e., shallow subsidence, sensu Cahoon et al. 1995) of the marsh substrate, the combination of which has been termed total subsidence (Cahoon et al. 1995). And if the marsh is to keep pace with a rising local sea level, then its rate of positive vertical change from accumulation of material must equal or be greater than the rate of total subsidence plus the local sea-level trend. Second, the existence of autocompaction indicates that accretion measures that had been assumed to raise the level of the marsh by an equal amount, likely overestimate elevation change, or underestimate it in the case of shallow expansion. Thus, assessing coastal wetland vulnerability to sea-level rise requires a quantitative understanding of not only RSLR but also marsh surface elevation change. To this end, the surface elevation table-marker horizon (SET-MH) method was developed (Cahoon et al. 1995, 2002a, b; Callaway et al. 2013) to provide simultaneous, millimeter accuracy measures of vertical accretion and surface elevation change, from which shallow subsidence or expansion of the marsh substrate is calculated. 


\section{COASTAL WETLAND}

Surface Elevation Table (SET)

\section{UPLAND}

Tide Gauge Benchmark Network and CGPS

\section{OCEAN}

Tide Gauge

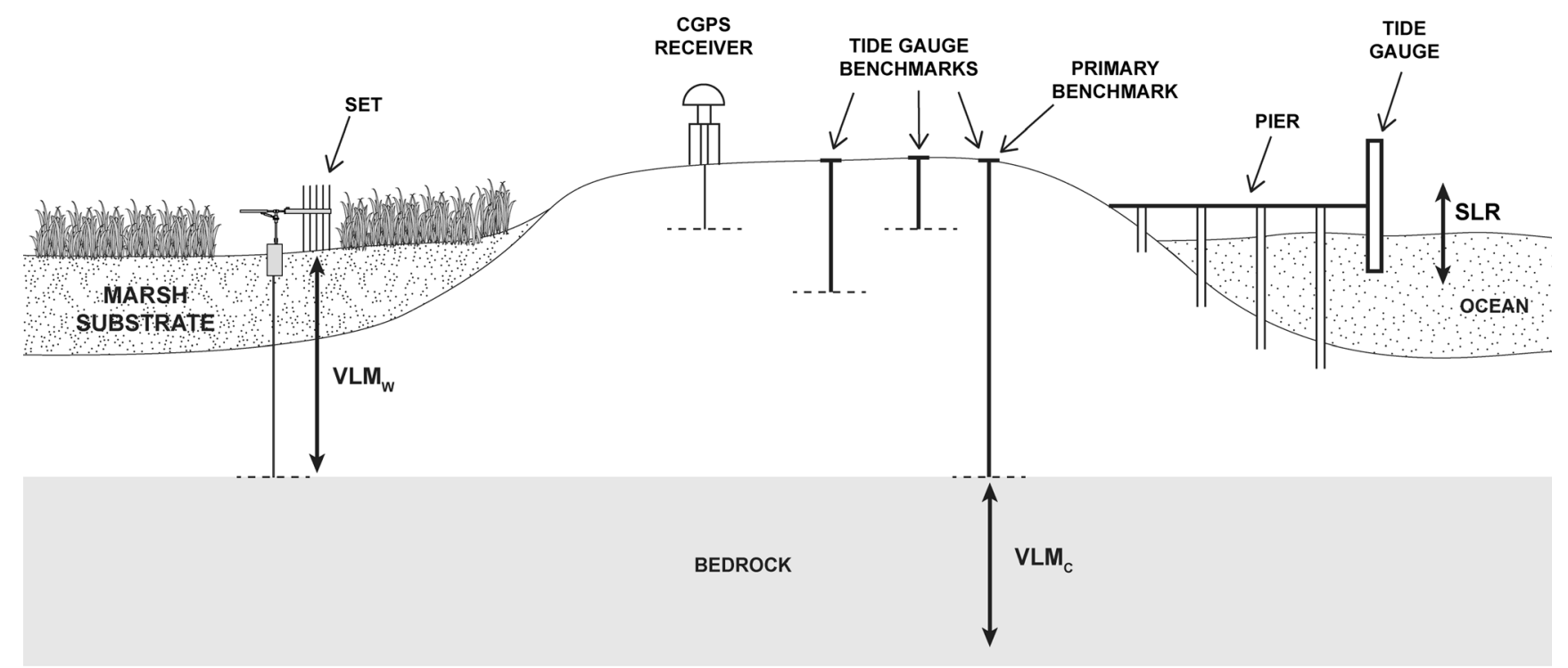

Fig 1 Conceptual diagram showing the relationship among measures of vertical land motion as recorded by the tide gauge benchmark network at a coastal upland area $\left(\mathrm{VLM}_{\mathrm{c}}\right)$ and the rod surface elevation table (RSET)

The SET is a portable, mechanical device that is attached to a pipe or rod mark driven into a wetland substrate (Boumans and Day 1993; Cahoon et al. 2002a, b; Callaway et al. 2013). The latest version of the SET attaches to a stainless steel rod driven typically $10-25 \mathrm{~m}$ (up to $40 \mathrm{~m}$ ) into the substrate, and is known as the Rod SET (Figs. 1 and 2), or RSET (Cahoon et al. 2002b; Callaway et al. 2013). The RSET is designed with leveling mechanisms so that each time the device is attached to a fixed position on the rod mark and leveled it will reoccupy the same reference plane in space (with respect to the rod mark) and remeasure the same point on the wetland surface at up to eight fixed positions around the mark. Surface elevation, relative to the base of the rod mark, is determined by lowering nine pins in the RSET arm to the wetland surface and measuring the height of each pin relative to the arm at each fixed position $(9$ pins $\times 8$ positions $=72$ maximum number of readings). Wetland surface elevation change $\left(\mathrm{VLM}_{\mathrm{w}}\right)$ is determined from repeat pin measurements of the marsh surface, and is the change in elevation relative to the base of the rod mark (i.e., the subsurface datum) that incorporates both surface (i.e., vertical accretion) and subsurface process influences on elevation occurring above the base of the rod mark (Fig. 2). The RSET does not measure any VLM $\mathrm{CM}_{\mathrm{c}}$ processes because they occur below the base of the rod mark (e.g., glacial isostatic adjustment and tectonics, Fig. 2), in what Cahoon et al. (1995) refer to as the deep subsidence zone. method in a coastal wetland $\left(\mathrm{VLM}_{\mathrm{w}}\right)$. The double-headed arrows for $\mathrm{VLM}_{\mathrm{w}}$ and $\mathrm{VLM}_{\mathrm{c}}$ indicate that vertical motion can be up or down, depending on the local setting and conditions

Measures of $\mathrm{VLM}_{\mathrm{w}}$ by the SET method and $\mathrm{VLM}_{\mathrm{c}}$ by a TGBM network connected to the global reference frame using GPS are independent and from different portions of the substrate profile. The SET method measures $\mathrm{VLM}_{\mathrm{w}}$ of the substrate overlying the SET rod base, which ideally is set on bedrock, by direct measurement of the wetland surface relative to the SET rod base (Cahoon et al. 1995; Cahoon et al. 2002b; Webb et al. 2013; Figs. 1 and 2). In contrast, the TGBM network connected to GPS provides a measure of $\mathrm{VLM}_{\mathrm{c}}$ at the base of each bench mark (Fig. 1), but does not record any motion occurring in the less stable materials overlying the benchmark base (Bevis et al. 2002). Thus, the $\mathrm{VLM}_{\mathrm{c}}$ measured at the TGBM network is not representative of the shallow $\mathrm{VLM}_{\mathrm{w}}$ dynamics of a typical wetland substrate. Thus, tide gauge RSLR can and usually does inadequately describe wetland submergence potential. Estimates of wetland vulnerability to sea-level rise should be based on the independent, high-resolution measures of both wetland elevation change and tide gauge RSLR.

\section{Subsurface Process Controls on Wetland Elevation}

The SET device can be used to quantify subsurface process influences on elevation when used in conjunction with the artificial soil marker horizon method for measuring vertical accretion. Wetland vertical accretion is the vertical accumulation of material related to soil development. Typically, 3 or 4 
Fig 2 Diagram showing the relationship between the measures of marsh surface elevation change $\left(\mathrm{VLM}_{\mathrm{w}}\right)$ made with the surface elevation table (SET) and vertical accretion (VA) of the marsh surface made with the marker horizon $(\mathrm{MH})$ method. The two methods are used to calculate shallow subsidence or shallow expansion $\left(\mathrm{VLM}_{\mathrm{s}}\right)$ that occurs between the marker horizon and the bottom of the SET rod mark (i.e., vertical accretion minus elevation change, Cahoon et al. 1995). Deep process influences $\left(\mathrm{VLM}_{\mathrm{c}}\right)$ on surface elevation change occurring below the SET rod mark are not captured by the SET method
Rod SET

( 2-40 meters deep)

Marker Horizon

(Surface)

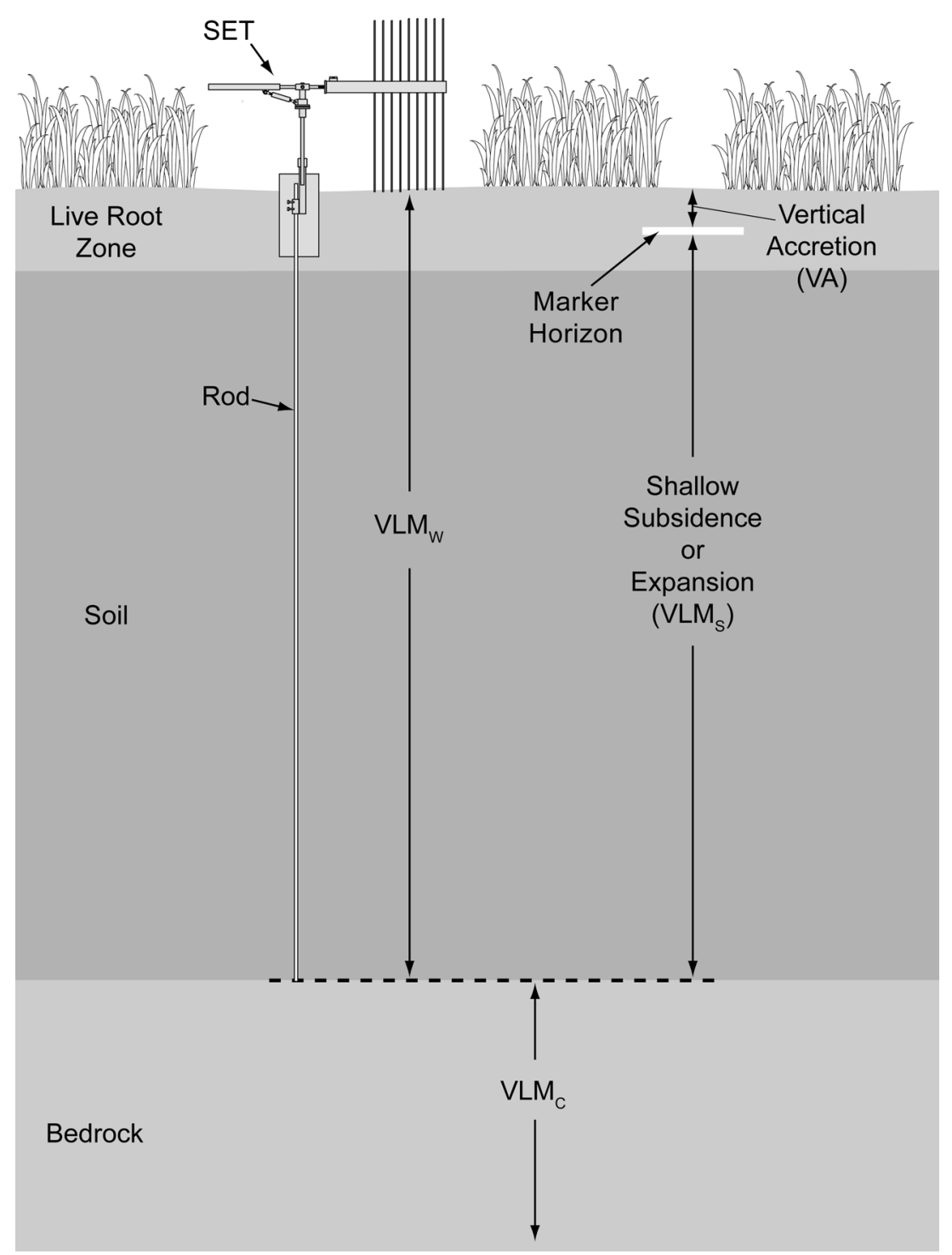

artificial soil marker horizons are established on the wetland surface around the SET (Fig. 2) by spreading powdered feldspar, a colloidal material that forms a solid layer when wet (Cahoon and Turner 1989), or sand in higher energy environments. Surface vertical accretion is determined by coring through the $\mathrm{MH}$ and measuring the thickness of material accumulated above it. Cahoon et al. (1995) calculated shallow subsidence or expansion $\left(\mathrm{VLM}_{\mathrm{S}}\right)$ occurring between the marker horizon and SET rod mark base (Fig. 2) as follows:

$\mathrm{VLM}_{\mathrm{s}}=\mathrm{VA}-\mathrm{VLM}_{\mathrm{w}}$

where VA is vertical accretion, and $\mathrm{VLM}_{\mathrm{w}}$ is the elevation trend from the SET. A negative value indicates shallow expansion; a positive value shallow subsidence. Processes in coastal wetlands driving shallow subsidence or expansion include root zone expansion from increased root volume (Cahoon et al. 2004; McKee et al. 2007; Langley et al. 2009; Cherry et al. 2009; and McKee 2011), root zone collapse from reduced root production, increased decomposition of plant roots, and loss of root volume (Ford and Grace 1998; Cahoon et al. 2003, 2004; McKee et al. 2007), shrink-swell related to changes in ground water level (Paquette et al. 2004; Whelan et al. 2005; Cahoon et al. 2011a; Rogers and Saintilan 2008), and compaction (Cahoon et al. 1995, 2000a, b; Lovelock et al. 2011). Major storms can affect all these processes either directly or indirectly (Cahoon 2006). Environmental drivers shown to influence shallow subsidence and expansion include plant herbivory, 
prescribed fire, drought, river stage, tides, elevated atmospheric $\mathrm{CO}_{2}$ concentrations, and nitrogen and phosphorus enrichment (Cahoon et al. 2009).

\section{Rates of Wetland Elevation Change}

The geographically extensive SET-MH datasets show that vertical accretion in coastal wetlands is a poor surrogate for marsh surface elevation change because of $\mathrm{VLM}_{\mathrm{s}}$ (Cahoon et al. 1999, 2006). A review of the 55 published SET and RSET literature sources identified by Webb et al. (2013) revealed 18 publications that used the SET-MH method and presented cumulative trends of wetland elevation change with a minimum duration of 3 years (see Supplemental Information). In all, data from these 18 publications were collated and analyzed for 89 salt marsh, mangrove, and tidal freshwater wetland sites (Online Resource 2). The elevation $\left(\mathrm{VLM}_{\mathrm{W}}\right)$ trend for $80 \%$ of these wetlands was significantly different from zero, indicating that the local tide gauge RSLR trend did not accurately reflect RSLR for these wetlands. Approximately $65 \%$ of the wetlands exhibited positive elevation trends up to $20.9 \mathrm{~mm} / \mathrm{y}$, and $15 \%$ of the wetlands exhibited negative elevation trends up to $-23.4 \mathrm{~mm} / \mathrm{y}$ (Table 1).

\section{Calculating Wetland Relative Sea-Level Rise Rates}

To fully understand the relative sea-level change a wetland is experiencing, given the highly dynamic nature of wetland surface elevation, the tide gauge RSLR is corrected by subtracting the wetland elevation change trend $\left(\mathrm{VLM}_{\mathrm{w}}\right)$. The relationship is expressed as follows:

$\mathrm{RSLR}_{\mathrm{wet}}=\mathrm{RSLR}_{-\mathrm{VLM}_{\mathrm{w}}}$

where RSLR $_{\text {wet }}$ is the relative sea-level rise rate at the wetland, RSLR is the relative sea-level rise rate at the tide gauge, and $\mathrm{VLM}_{\mathrm{W}}$ is the wetland surface elevation trend from the SET measurements. RSLR ${ }_{\text {wet }}$ more accurately estimates the direction and magnitude of the sea-level trend in relation to the wetland surface than RSLR. In addition, RSLR ${ }_{\text {wet }}$ quantifies the elevation rate deficit or surplus (sensu Cahoon et al. 1995) the wetland is experiencing expressed in terms of the relative sea-level slope (i.e., sea level is rising, unchanged, or falling in relation to the wetland surface). A negative RSLR wet trend (i.e., RSLR $<\mathrm{VLM}_{\mathrm{w}}$ ) indicates an elevation rate surplus exists and sea level is becoming lower in relation to the wetland surface. A positive $\operatorname{RSLR}_{w e t}$ trend $\left(\mathrm{RSLR}>\mathrm{VLM}_{\mathrm{w}}\right)$ indicates sea level is becoming higher in relation to the wetland surface, and an elevation rate deficit exists. A zero $\mathrm{RSLR}_{\text {wet }}$ trend $\left(\mathrm{RSLR}=\mathrm{VLM}_{\mathrm{w}}\right)$ indicates sea level is unchanged in relation to the wetland surface because the rate of wetland vertical development is keeping pace with RSLR.

Earlier efforts to revise RSLR using SET-MH data (Rybczyk and Cahoon 2002; Cahoon et al. 2011b) involved adding wetland $\mathrm{VLM}_{\mathrm{s}}$ to RSLR, but did not add vertical accretion, which together would equal $\mathrm{VLM}_{\mathrm{w}}$. Thus revised RSLR, the term used in these earlier studies to describe RSLR $_{\text {wet, }}$, was overestimated. For example, RSLR ${ }_{\text {wet }}$ for Bayou Chitigue using Eq. [2] would be $15.5 \mathrm{~mm} / \mathrm{y}$, instead of $33.7 \mathrm{~mm} / \mathrm{y}$ as reported by Rybczyk and Cahoon (2002).

Table 1 Wetland RSLR $\left(\operatorname{RSLR}_{\text {wet }}\right)$ trends calculated from published wetland elevation $\left(\mathrm{VLM}_{\mathrm{w}}\right)$ trends measured with the SET method and where local tide gauge RSLR trends were available (see Supplemental Information, Table S1)

\begin{tabular}{|c|c|c|c|c|c|c|c|c|}
\hline \multirow[b]{2}{*}{ Wetland type } & \multirow[b]{2}{*}{ Wetland $n$} & \multirow[b]{2}{*}{ Trend } & \multicolumn{3}{|l|}{$\mathrm{VLM}_{\mathrm{w}}$} & \multicolumn{3}{|l|}{$\mathrm{RSLR}_{\text {wet }}$} \\
\hline & & & Wetland $n$ & $\%$ Total & Range (mm/y) & Wetland $n^{\mathrm{a}}$ & $\%$ Total & Range (mm/y) \\
\hline \multirow[t]{3}{*}{ All types } & \multirow[t]{3}{*}{89} & Negative & 13 & 15 & -0.4 to -23.4 & 34 & 39 & -0.1 to -16.6 \\
\hline & & Zero & 18 & 20 & - & 3 & 3 & - \\
\hline & & Positive & 58 & 65 & 0.7 to 20.9 & 50 & 58 & 0.1 to 29.4 \\
\hline \multirow[t]{3}{*}{ Saltmarsh } & \multirow[t]{3}{*}{58} & Negative & 7 & 12 & -2 to -23.4 & 22 & 39 & -0.1 to -16.6 \\
\hline & & Zero & 11 & 19 & - & 1 & 2 & - \\
\hline & & Positive & 40 & 69 & 1 to 20.9 & 33 & 59 & 0.3 to 29.4 \\
\hline \multirow[t]{3}{*}{ Mangrove } & \multirow[t]{3}{*}{26} & Negative & 4 & 15 & -2.6 to -3.7 & 10 & 38 & -1.7 to -7.8 \\
\hline & & Zero & 7 & 27 & - & 2 & 8 & - \\
\hline & & Positive & 15 & 58 & 1.1 to 9.9 & 14 & 54 & 0.1 to 5.2 \\
\hline \multirow[t]{3}{*}{ Fresh } & \multirow[t]{3}{*}{5} & Negative & 2 & 40 & -0.4 to -6.4 & 2 & 40 & -2.1 to -9.5 \\
\hline & & Zero & 0 & 0 & - & 0 & 0 & - \\
\hline & & Positive & 3 & 60 & 0.7 to 12.9 & 3 & 60 & 3.8 to 9.8 \\
\hline
\end{tabular}

${ }^{\mathrm{a}}$ The RSLR rate was not reported for two of the 89 wetlands. Thus, RSLR ${ }_{\text {wet }}$ was calculated for only 87 of the wetlands where VLM $_{\mathrm{w}}$ was measured 


\section{Rates of Wetland RSLR}

The historic, local RSLR rates were available for calculating RSLR $_{\text {wet }}$ in all but one of the 18 studies and were compared directly to the $\mathrm{VLM}_{\mathrm{w}}$ values presented in Table 1 . RSLR was negative at 34 of the 87 wetlands ( $39 \%$ ), where sea level was becoming lower relative to the wetland surface at a rate of -0.1 to $-16.6 \mathrm{~mm} / \mathrm{y}$ (Table 1 ). These wetlands are experienc-

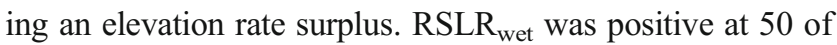
the 87 wetlands ( $58 \%$ ), where sea level was becoming higher relative to the wetland surface at a rate of 0.1 to $29.4 \mathrm{~mm} / \mathrm{y}$. These wetlands are experiencing an elevation rate deficit. The remaining three wetlands were keeping pace with the local rate of sea-level rise. The proportion of wetlands with negative and positive RSLR $\mathrm{wet}_{\mathrm{wet}}$ was consistent (approximately $40 \%$ and $60 \%$ ) across saltmarsh, mangrove, and fresh wetland types (Table 1). The highest negative and positive $\mathrm{VLM}_{\mathrm{w}}$ trend and elevation rate surplus and deficit were reported from saltmarsh wetlands. The range in negative and positive $\mathrm{VLM}_{\mathrm{w}}$ and elevation rate surplus and deficit was smaller in mangrove and fresh wetlands.

\section{Caveats of Calculating RSLR $_{\text {wet }}$}

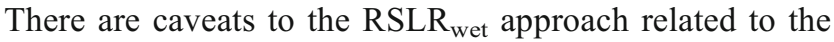
temporal and spatial variability in wetland elevation and sea level data. High spatial variability in $\mathrm{VLM}_{\mathrm{w}}$ among wetland sites requires that $\mathrm{RSLR}_{\text {wet }}$ be calculated for every wetland site, not extrapolated from nearby wetlands. In addition, high spatial variability in sea level indicates that distance from a wetland to a long-term tide gauge could be a drawback given that sea level recorded at the gauge does not necessarily transfer accurately over long distances (Mossman et al. 2012). Yet, in many regions, sea level trends and variations are highly correlated, thus suggesting some ability to extrapolate depending on underlying geology.

Given the high variability in both trends, perhaps the most important caveat is that comparisons of $\mathrm{VLM}_{\mathrm{w}}$ and RSLR trends are confounded by the difference in record lengths. The longest SET data record available is near 20 years duration, but most are considerably shorter $(<10$ years). Relative sealevel trends from tide gauges should be a minimum of several decades, up to 60 to 70 years duration, to provide a meaningful trend, given the high level of noise in the sea level data (Peltier 2001). Ideally, both trends would be measured over the same period of time and for several decades. Lacking wetland elevation trends of a similar long duration as tide gauge records, two approaches have been used to compare these datasets of disparate length, each with its own shortcomings. First, the approach most often used is to assume that the historic sea-level trend existed during the shorter duration wetland elevation trend, and the two trends are compared directly. This assumption may not be realistic in every instance. Alternatively, a short-term sea-level trend is calculated from the tide gauge data for the same time period as the wetland elevation trend (e.g., 5 years), and the trends are compared directly. This approach shows the shortterm relationship of wetland elevation with recent sealevel change but not with the long-term sea-level trend. In addition, this approach can be confounded by high levels of variability that typically occur in short duration records of both trends. Thus, calculations of RSLR ${ }_{\text {wet }}$ must be interpreted and reported taking these caveats into account. See McIvor et al. (2013) for an excellent overview of the issues related to comparing surface elevation change data with sea-level rise data.

To address these caveats, efforts need to be made to colocate tide gauges and SET-MH stations near each other, as is being done at the twenty-eight NOAA National Estuarine Research Reserves (NERR) located in estuaries and associated wetlands along the coasts of the USA (NERR 2012), and in Louisiana, USA, where each of the 390 wetland monitoring stations that make up the State of Louisiana Coast-wide Reference Monitoring System (CRMS) includes a water level gauge and a SET-MH station (Steyer et al. 2003). The CRMS and NERR long-term monitoring networks provide co-located, continuous records of local relative sea level change, vertical accretion, surface elevation change $\left(\mathrm{VLM}_{\mathrm{w}}\right)$, and $\mathrm{VLM}_{\mathrm{s}}$ across the range of ecological conditions in the coastal marshes of Louisiana and the specific coastal setting where each NERR is located.

In sum, understanding the management and adaptation implications of rising sea level on coastal wetlands requires complete knowledge of local RSLR rates with respect to coastal habitats, specifically vertically dynamic shoreline and near-shore environments. Thus, coastal wetland managers need high-resolution information on wetland elevation change relative to local sea level change in order to improve assessments of submergence potential and to better manage the valuable ecosystem services provided by coastal wetlands. To this end, this paper synthesized the current methodology for measuring wetland elevation dynamics and RLSR from tide gauges, and provides a standard method and vocabulary for estimating and describing the potential for wetland submergence.

Acknowledgments K. Boone and J. Lynch drafted Fig. 1, and J. Lynch drafted Fig. 2. I am deeply indebted to the following individuals for providing critical reviews of earlier draft versions of this manuscript: S. Gill, P. Hensel, B. Horton, J. Lynch, K. Krauss, K. McKee, two anonymous reviewers, and C. Currin. Any use of trade, product, or firm names is for descriptive purposes only and does not imply endorsement by the US Government. This research was funded by the U.S. Geological Survey Climate and Land Use Research \& Development program. 


\section{References}

Baker, T.F. 1993. Absolute sea level measurements, climate change and vertical crustal movements. Global and Planetary Change 8: 149159

Bevis, M., W. Scherer, and M. Merrifield. 2002. Technical issues and recommendations related to the installation of continuous GPS stations at tide gauges. Marine Geodesy 25: 87-99.

Boumans, R.M.J., and J.W. Day Jr. 1993. High precision measurements of sediment elevation in shallow coastal areas using a sedimentationerosion table. Estuaries 16: 375-380.

Cahoon, D.R. 2006. A review of major storm impacts on coastal wetland elevation. Estuaries and Coasts 29(6A): 889-898.

Cahoon, D.R., and R.E. Turner. 1989. Accretion and canal impacts in a rapidly subsiding wetland II: feldspar marker horizon technique. Estuaries 12(4): 260-268.

Cahoon, D.R., D.J. Reed, and J.W. Day Jr. 1995. Estimating shallow subsidence in microtidal salt marshes of the southeastern United States: Kaye and Barghoorn revisited. Marine Geology 128: 1-9.

Cahoon, D.R., J.W. Day Jr., and D.J. Reed. 1999. The influence of surface and shallow subsurface soil processes on wetland elevation: a synthesis. Current Topics in Wetland Biogeochemistry 3: 72-88.

Cahoon, D.R., J. French, T. Spencer, D.J. Reed, and I. Moller. 2000a. Vertical accretion versus elevational adjustment in UK saltmarshes: an evaluation of alternative methodologies. In Coastal and estuarine environments: sedimentology, geomorphology and geoarchaeology, ed. K. Pye and J.R.L. Allen, 223-238. London: Geological Society, Special Publications. 175.

Cahoon, D.R., P.E. Marin, B.K. Black, and J.C. Lynch. 2000b. A method for measuring vertical accretion, elevation, and compaction of soft, shallow-water sediments. Journal of Sedimentary Research 70: $1250-1253$

Cahoon, D.R., J.C. Lynch, P. Hensel, R. Boumans, B.C. Perez, B. Segura, and J.W. Day Jr. 2002a. High precision measurement of wetland sediment elevation: I. recent improvements to the sedimentationerosion table. Journal of Sedimentary Research 72(5): 730-733.

Cahoon, D.R., J.C. Lynch, B.C. Perez, B. Segura, R. Holland, C. Stelly, G. Stephenson, and P. Hensel. 2002b. High precision measurement of wetland sediment elevation: II. The rod surface elevation table. Journal of Sedimentary Research 72(5): 734-739.

Cahoon, D.R., P. Hensel, J. Rybczyk, K. McKee, C.E. Proffitt, and B.C. Perez. 2003. Mass tree mortality leads to mangrove peat collapse at Bay Islands, Honduras after Hurricane Mitch. Journal of Ecology 91: 1093-1105.

Cahoon, D.R., M.A. Ford, and P. Hensel. 2004. Ecogeomorphology of Spartina patens-dominated tidal marshes: soil organic matter accumulation, marsh elevation dynamics, and disturbance. In The ecogeomorphology of tidal marshes, coastal estuarine studies, vol. 59, ed. S. Fagherazzi, M. Marani, and L.K. Blum, 247-266. Washington: American Geophysical Union.

Cahoon, D.R., P. Hensel, T. Spencer, D.J. Reed, K.L. McKee, and N. Saintilan. 2006. Coastal wetland vulnerability to relative sea-level rise: wetland elevation trends and process controls. In Wetlands and natural resource management, ecological studies, vol. 190, ed. J.T.A. Verhoeven, B. Beltman, R. Bobbink, and D. Whigham, 271-292. Berlin: Springer.

Cahoon, D.R., D.J. Reed, A. Kolker, M. Brinson, J.C. Stevenson, S. Riggs, R. Christian, E. Reyes, C. Voss, and D. Kunz. 2009. Coastal wetland sustainability. In Coastal sensitivity to sea-level rise: a focus on the mid-Atlantic region, a report by the US climate change science program and the subcommittee on global change research, ed. J.G. Titus, K.E. Anderson, D.R. Cahoon, S. Gill, E.R. Thieler, and S.J. Williams, 57-72. Washington: US Environmental Protection Agency.
Cahoon, D.R., B.C. Perez, B. Segura, and J.C. Lynch. 2011a. Elevation trends and shrink-swell response of wetland soils to flooding and drying. Estuarine, Coastal and Shelf Science 91: 463-568.

Cahoon, D.R., D.A. White, and J.C. Lynch. 2011b. Sediment infilling and wetland formation dynamics in an active crevasse splay of the Mississippi River delta. Geomorphology 131: 57-68.

Callaway, J.C., D.R. Cahoon, and J.C. Lynch. 2013. The surface elevation table-marker horizon method for measuring wetland accretion and elevation dynamics. In Methods in Biogeochemistry of Wetlands. SSSA Book Series, vol. 10, ed. R.D. De Laune, K.R. Reddy, C.J. Richardson, J.P. Megonigal, 901-917. Madison: Soil Science Society of America.

Cherry, J.A., K.L. McKee, and J.B. Grace. 2009. Elevated $\mathrm{CO}_{2}$ enhances biological contributions to elevation change in coastal wetlands by offsetting stressors associated with sea-level rise. Journal of Ecology 97: 67-77.

Ford, M.A., and J.B. Grace. 1998. Effect of vertebrate herbivores on soil processes, plant biomass, litter accumulation and soil elevation changes in a coastal marsh. Journal of Ecology 86: 974-982.

Intergovernmental Oceanographic Commission of UNESCO. 2006. Manual on Sea-level Measurements and Interpretation, Volume IV: an update to 2006, IOC Manuals and Guides No. 14, vol. IV; JCOMM Technical Report No. 31; WMO/TD No. 1339, Paris, 78 $\mathrm{pp}$.

Kaye, C.A., and E.S. Barghoorn. 1964. Late quaternary sea level change and crustal rise at Boston, Massachusetts, with notes on autocompaction of peat. Geological Society of America Bulletin 75: 63-80.

Langley, J.A., K.L. McKee, D.R. Cahoon, J.A. Cherry, and J.P. Megonigal. 2009. Elevated $\mathrm{CO}_{2}$ stimulates marsh elevation gain, counterbalancing sea-level rise. Proceedings of the National Academy of Sciences 106: 6182-6186.

Lovelock, C.E., V. Bennion, A. Grinham, and D.R. Cahoon. 2011. The role of surface and subsurface processes in keeping pace with sealevel rise in intertidal wetlands of Moreton Bay, Queensland, Australia. Ecosystems 14: 745-757.

McIvor, A., T. Spencer, I. Moller, and M. Spalding. 2013. The response of mangrove soil surface elevation to sea level rise. Natural Coastal Protection Series: Report 3, Cambridge Coastal Research Unit Working Paper 42. Published by The Nature Conservancy and Wetlands International. 59 pages. ISSN 2050-7941. URL: http:// coastalresilience.org/science/mangroves/surface-elevation-and-sealevel-rise

McKee, K.L. 2011. Biophysical controls on accretion and elevation change in Caribbean mangrove ecosystems. Estuarine, Coastal and Shelf Science 91: 475-483.

McKee, K.L., D.R. Cahoon, and I.C. Feller. 2007. Caribbean mangroves adjust to rising sea level through biotic controls on change in soil elevation. Global Ecology and Biogeography 16: 545-556.

Mossman, H., A. Davy, and A. Grant. 2012. Quantifying local variation in tidal regime using depth-logging fish tags. Estuarine, Coastal and Shelf Science 96: 122-128.

NERR. 2012. Sentinel sites program guidance for climate change impacts, National Estuarine Research Reserve System, Office of Ocean and Coastal Resource Management. Silver Spring: NOAA National Ocean Service. 23 pp.

Paquette, C.H., K.L. Sundberg, R.M.J. Boumans, and G.L. Chmura. 2004. Changes in salt marsh surface elevation due to variability in evapotranspiration and tidal flooding. Estuaries 27: 82-89.

Peltier, W.R. 2001. Global glacial isostatic adjustment and modern instrumental records of relative sea level history. In Sea level rise: history and consequences, vol. 75, ed. B.C. Douglas, M.S. Kearney, and S.P. Leatherman, 65-95. San Diego: Academic Press, International Geophysics Series. 
Rogers, K., and N. Saintilan. 2008. Relationships between surface elevation and groundwater in mangrove forests of southeast Australia. Journal of Coastal Research 24: $63-69$.

Rybczyk, J.M., and D.R. Cahoon. 2002. Estimating the potential for submergence for two subsiding wetlands in the Mississippi River delta. Estuaries 25: 985-998.

Steyer, G.D., C.E. Sasser, J.M. Visser, E.M. Swenson, J.A. Nyman, and R.C. Raynie. 2003. A proposed coast-wide reference monitoring system for evaluating wetland restoration trajectories in Louisiana. Environmental Monitoring and Assessment 81: 107-117.

Webb, E.L., D.A. Friess, K. Krauss, D.R. Cahoon, G.R. Guntenspergen, and J. Phelps. 2013. A global standard for monitoring coastal wetland vulnerability to accelerated sea-level rise. Nature Climate Change 3: 458-465.

Whelan, K.R.T., T.J. Smith III, D.R. Cahoon, J.C. Lynch, and G.H. Anderson. 2005. Groundwater control of mangrove surface elevation: shrink-swell of mangrove soils varies with depth. Estuaries 28: 833843. 
Article title: Estimating relative sea-level rise and submergence potential at a coastal wetland

Donald R. Cahoon

US Geological Survey, Patuxent Wildlife Research Center, 10300 Baltimore Avenue, c/o BARC-East, Building 308, Beltsville, MD 20705 USA, email: dcahoon@usgs.gov

\section{SUPPLEMENTAL INFORMATION}

\section{DATA SOURCES FOR TABLE 1 and TABLE S1}

The analyses of surface elevation table (SET) data presented in Table 1 were conducted on data found in the 18 publications listed below. Only publications that contained SET data and presented cumulative trends (3-year minimum duration) of surface elevation change for natural and restored salt marsh, mangrove, and tidal freshwater wetland sites (i.e., excluding open water and mudflat sites, and experimentally manipulated wetland sites) were included in the analyses presented in Table 1 . The data used in the analyses, and taken from these 18 publications, are listed in the Supplemental Information Table S1.

\section{REFERENCES}

1. Baldwin, A. H., R. S. Hammerschlag, and D. R. Cahoon. 2009. Evaluation of restored tidal freshwater wetlands. In Coastal Wetlands: an integrated ecosystem approach, ed. G. M. E. Perillo, E. Wolanski, D. R. Cahoon, and M. Brinson, 801-831. Amsterdam: Elsevier

2. Boumans, R., M. Ceroni, D. Burdick, D. R. Cahoon, and C. Swarth. 2002. Sediment elevation dynamics in tidal marshes: functional assessment of accretionary biofilters, CICEET Final Report for the period August 15, 1999 through August 15, 2002, pp. 44. 
3. Cahoon, D. R., J. French, T. Spencer, D. J. Reed, and I. Moller. 2000a. Vertical accretion versus elevational adjustment in UK saltmarshes: an evaluation of alternative methodologies. In Coastal and Estuarine Environments: Sedimentology, Geomorphology and Geoarchaeology, ed. K. Pye and J. R. L. Allen, 223-238. London: Geological Society, Special Publications, 175.

4. Cahoon, D. R., D. A. White, and J. C. Lynch. 2011b. Sediment infilling and wetland formation dynamics in an active crevasse splay of the Mississippi River delta. Geomorphology 131: 57-68.

5. Cornu, C. E., and S. Sadro. 2002. Physical and functional responses to experimental marsh surface elevation manipulation in Coos Bay's South Slough. Restoration Ecology 10: 474-486.

6. Day, J. W., Jr., J. Rybczyk, F. Scarton, A. Rismondo, D. Are, and G. Cecconi. 1999. Soil accretionary dynamics, sea-level rise and the survival of wetlands in Venice Lagoon: a field and modeling approach. Estuarine, Coastal and Shelf Science 49: 607-628.

7. Erwin, R. M., D. R. Cahoon, D. J. Prosser, G. M. Sanders, and P. Hensel. 2006. Surface elevation dynamics in vegetated Spartina marshes versus unvegetated tidal ponds along the mid-Atlantic coast, USA, with implications to waterbirds. Estuaries and Coasts 29: 96-106.

8. French, J. R., and H. Burningham. 2003. Tidal marsh sedimentation versus sea-level rise: a southeast England estuarine perspective. Proceedings of the International Conference on Coastal Sediments 2003. May 18-23, 2003, Clearwater Beach, FL, USA. CD-ROM 
Published by World Scientific Publishing Corp. and East Meets West Productions, Corpus Christi, Texas, USA. ISBN 981-238-422-7.

9. Hensel, P. F., J. W. Day, Jr., and D. Pont. 1999. Wetland vertical accretion and soil elevation change in the Rhone River delta, France: the importance of riverine flooding. Journal of Coastal Research 15(3): 668-681.

10. Ibanez, C., P. J. Sharpe, J. W. Day, Jr., J. N. Day, and N. Prat. 2010. Vertical accretion and relative sea level rise in the Ebro delta wetlands (Catalonia, Spain). Wetlands 30: 979-988.

11. Krauss, K. W., D. R. Cahoon, J. A. Allen, K. C. Ewel, J. C. Lynch, and N. Cormier. 2010. Surface elevation change and susceptibility of different mangrove zones to sea-level rise on Pacific high islands of Micronesia. Ecosystems 13: 129-143.

12. Kroes, D. E., and C. R. Hupp. 2010. The effect of channelization on floodplain sediment deposition and subsidence along the Pocomoke River, Maryland. Journal of the American Water Resources Association 46(4): 686-699.

13. Lane, R. R., J. W. Day, Jr., and J. N. Day. 2006. Wetland surface elevation, vertical accretion, and subsidence at three Louisiana estuaries receiving diverted Mississippi River water. Wetlands 26(4): 1130-1142. 
14. Lovelock, C. E., V. Bennion, A. Grinham, and D. R. Cahoon. 2011. The role of surface and subsurface processes in keeping pace with sea-level rise in intertidal wetlands of Moreton Bay, Queensland, Australia. Ecosystems 14: 745-757.

15. McKee, K. L., D. R. Cahoon, and I. C. Feller. 2007. Caribbean mangroves adjust to rising sea level through biotic controls on change in soil elevation. Global Ecology and Biogeography 16: 545-556.

16. McKee, K. L. 2011. Biophysical controls on accretion and elevation change in Caribbean mangrove ecosystems. Estuarine, Coastal and Shelf Science 91: 475-483.

17. Rogers, K., K. M. Wilton, and N. Saintilan. 2006. Vegetation change and surface elevation dynamics in estuarine wetlands of southeast Australia. Estuarine, Coastal and Shelf Science 66: 559-569.

18. Rybczyk, J. M., and D. R. Cahoon. 2002. Estimating the potential for submergence for two subsiding wetlands in the Mississippi River delta. Estuaries 25: 985-998. 


\begin{tabular}{|c|c|c|c|c|c|c|c|}
\hline $\begin{array}{l}\text { Wetland } \\
\text { Type }\end{array}$ & Location & $\begin{array}{c}\text { Elevation Rate, } \\
\text { VLM }_{\mathrm{w}} \\
(\mathrm{mm} / \mathrm{y})^{1} \\
\end{array}$ & $\begin{array}{l}\text { Record } \\
\text { Length } \\
\text { (years) } \\
\end{array}$ & $n^{2}$ & $\begin{array}{c}\text { RSLR } \\
(\mathrm{mm} / \mathrm{y})^{3}\end{array}$ & $\begin{array}{c}\text { Wetland } \\
\text { RSLR } \\
(\mathrm{mm} / \mathrm{y})^{4}\end{array}$ & $\begin{array}{l}\text { Ref. } \\
\text { No. }^{5}\end{array}$ \\
\hline \multicolumn{8}{|c|}{$\begin{array}{c}\text { HERBACEOUS } \\
\text { MARSH }\end{array}$} \\
\hline & UNITED STATES & & & & & & \\
\hline & & & & & & & \\
\hline Saltmarsh & $\begin{array}{l}\text { Louisiana - } \\
\text { Bayou Chitigue }\end{array}$ & $2.2+/-0.6$ & 8 & 3 & 13.3 & 11.1 & 18 \\
\hline Saltmarsh & $\begin{array}{l}\text { Louisiana - } \\
\text { Old Oyster Bayou }\end{array}$ & $3.6+/-0.8$ & 8 & 3 & 9.0 & 5.4 & 18 \\
\hline \multirow[t]{10}{*}{ Saltmarsh } & $\begin{array}{l}\text { Louisiana - } \\
\text { Caernarvon diversion }\end{array}$ & & & & & & \\
\hline & C-Near & $4.2+/-0.2$ & 4 & 2 & 3 & -1.2 & 13 \\
\hline & C-Mid & $1.6+/-3.1 \mathrm{~ns}$ & 4 & 2 & 3 & 3 & 13 \\
\hline & C-Far & $3.6+/-2.5$ & 4 & 2 & 3 & -0.6 & 13 \\
\hline & W-Near & $5.6+/-2.6$ & 4 & 2 & 7 & 1.4 & 13 \\
\hline & W-Mid & $7.0+/-1.1$ & 4 & 2 & 7 & 0 & 13 \\
\hline & W-Far & $2.7+/-0.9$ & 4 & 2 & 7 & 4.3 & 13 \\
\hline & V-Near & $-23.4+/-4.1$ & 4 & 2 & 6 & 29.4 & 13 \\
\hline & V-Mid & $-11.8+/-2.6$ & 4 & 2 & 6 & 17.8 & 13 \\
\hline & V-Far & $-11.0+/-2.4$ & 4 & 2 & 6 & 17.0 & 13 \\
\hline \multirow[t]{2}{*}{$\begin{array}{l}\text { Fresh- } \\
\text { Brackish }\end{array}$} & $\begin{array}{l}\text { Louisiana - } \\
\text { Balize delta crevasse }\end{array}$ & & & & & & \\
\hline & Forest & $0.7+/-0.6$ & 4 & 2 & 10.0 & 9.3 & 4 \\
\hline Saltmarsh & $\begin{array}{l}\text { Massachusetts - } \\
\text { Nauset Marsh }\end{array}$ & $2.7+/-0.7$ & 5 & 4 & 2.6 & -0.1 & 7 \\
\hline Saltmarsh & $\begin{array}{l}\text { New Jersey - } \\
\text { Little Beach }\end{array}$ & $1.7+/-1.0$ & 3 & 3 & 4.1 & 2.4 & 7 \\
\hline \multirow[t]{4}{*}{ Saltmarsh } & $\begin{array}{l}\text { Virginia - } \\
\text { Wachapreague }\end{array}$ & & & & & & \\
\hline & High marsh & $1.4+/-1.1$ & 4 & 3 & 3.9 & 2.5 & 7 \\
\hline & Mid marsh & $0.7+/-1.1 \mathrm{~ns}$ & 4 & 3 & 3.9 & 3.9 & 7 \\
\hline & $\begin{array}{l}\text { Virginia - } \\
\text { Mockhorn }\end{array}$ & $1.4+/-1.8 \mathrm{~ns}$ & 4 & 2 & 3.9 & 3.9 & 7 \\
\hline
\end{tabular}




\begin{tabular}{|c|c|c|c|c|c|c|c|}
\hline Fresh & $\begin{array}{l}\text { Washington, DC- } \\
\text { Anacostia River }\end{array}$ & & & & & & \\
\hline & Kingman marsh & $12.9+/-3.0$ & 3 & 5 & $3.4^{6}$ & -9.5 & 1 \\
\hline & Kenilworth marsh & $5.5+/-3.9$ & 3 & 5 & 3.4 & -2.1 & 1 \\
\hline \multirow[t]{3}{*}{$\begin{array}{l}\text { Fresh - } \\
\text { Brackish }\end{array}$} & $\begin{array}{l}\text { Maryland- } \\
\text { Pocomoke River }\end{array}$ & & & & & & \\
\hline & Willards & -6.4 & 4 & 3 & $3.4^{7}$ & 9.8 & 12 \\
\hline & Porter's Crossing & -0.4 & 4 & 3 & 3.4 & 3.8 & 12 \\
\hline \multirow[t]{3}{*}{ Saltmarsh } & $\begin{array}{l}\text { Oregon- } \\
\text { South Slough }\end{array}$ & & & & & & \\
\hline & Danger Point & $12.5+/-4.7$ & 3 & 1 & NA & NA & 5 \\
\hline & Tom's Creek & $20.9+/-4.1$ & 3 & 1 & $\mathrm{NA}$ & NA & 5 \\
\hline \multirow[t]{5}{*}{ Saltmarsh } & $\begin{array}{l}\text { California - } \\
\text { Tijuana Slough }\end{array}$ & & & & & & \\
\hline & Low marsh & $3.0+/-0.2$ & 9 & 3 & $2^{8}$ & -1 & 2 \\
\hline & High marsh & $0.1+/-0.4 \mathrm{~ns}$ & 9 & 3 & 2 & 2 & 2 \\
\hline & & & & & & & \\
\hline & UNITED KINGDOM & & & & & & \\
\hline \multirow[t]{6}{*}{ Saltmarsh } & Scolt Head Island & & & & & & \\
\hline & Hut marsh-creek & $6.4+/-0.3$ & 4 & 2 & 2 & 4.4 & 3 \\
\hline & Hut marsh - interior & $6.2+/-0.2$ & 4 & 2 & 2 & 4.2 & 3 \\
\hline & Hut marsh - high & $2.9+/-0.2$ & 4 & 2 & 2 & 0.9 & 3 \\
\hline & Spartina marsh & $7.0+/-0.3$ & 4 & 1 & 2 & 5.0 & 3 \\
\hline & Salicornia marsh & $5.4+/-0.3$ & 4 & 1 & 2 & 3.4 & 3 \\
\hline \multirow[t]{3}{*}{ Saltmarsh } & $\begin{array}{l}\text { Stiffkey- } \\
\text { backbarrier marsh }\end{array}$ & & & & & & \\
\hline & creekside & $2.4+/-0.5$ & 3 & 1 & 2 & 0.4 & 3 \\
\hline & interior & $4.4+/-0.4$ & 3 & 1 & 2 & 2.4 & 3 \\
\hline \multirow[t]{8}{*}{ Saltmarsh } & $\begin{array}{l}\text { Blythe Estuary - } \\
\text { Reydon transect }\end{array}$ & & & & & & \\
\hline & riverside & 12.1 & 5 & 1 & 2.4 & -9.7 & 8 \\
\hline & interior 1 & 3.7 & 5 & 1 & 2.4 & -1.3 & 8 \\
\hline & interior 2 & 2.7 & 5 & 1 & 2.4 & -0.3 & 8 \\
\hline & interior 3 & 3.3 & 5 & 1 & 2.4 & -0.9 & 8 \\
\hline & Bulcamp transect & & & & & & \\
\hline & riverside & 6.1 & 4 & 2 & 2.4 & -3.7 & 8 \\
\hline & interior & 4.6 & 4 & 2 & 2.4 & -2.2 & 8 \\
\hline
\end{tabular}




\begin{tabular}{|c|c|c|c|c|c|c|c|}
\hline & & & & & & & \\
\hline & & & & & & & \\
\hline & FRANCE & & & & & & \\
\hline \multirow{5}{*}{ Saltmarsh } & Rhone River delta & & & & & & \\
\hline & riverine & $11.3+/-6.1$ & 3 & 1 & 3.7 & -7.6 & 9 \\
\hline & margin & $0.6+/-1.5 \mathrm{~ns}$ & 3 & 1 & 3.7 & 3.7 & 9 \\
\hline & & & & & & & \\
\hline & SPAIN & & & & & & \\
\hline \multirow{6}{*}{ Saltmarsh } & Ebro River delta & & & . & & & \\
\hline & Garxal & $6.6+/-2.4$ & 9.5 & 2 & 3 & -3.6 & 10 \\
\hline & Buda backshore & $4.9+/-2.4$ & 9.5 & 2 & 3 & -1.9 & 10 \\
\hline & Migjorn & $1.4+/-2.4 \mathrm{~ns}$ & 3 & 2 & 3 & 1.6 & 10 \\
\hline & & & & & & & \\
\hline & ITALY & & & & & & \\
\hline \multirow[t]{13}{*}{ Saltmarsh } & Venice Lagoon & & & & & & \\
\hline & Dese 1 & $4^{9}$ & 3 & 2 & 2.4 & -1.6 & 6 \\
\hline & Dese 2 & 5 & 3 & 2 & 2.4 & -2.6 & 6 \\
\hline & Laghi & 4 & 3 & 2 & 2.4 & -1.6 & 6 \\
\hline & San Felice 1 & 1 & 3 & 2 & 2.4 & 1.4 & 6 \\
\hline & San Felice 2 & 3 & 3 & 2 & 2.4 & -0.6 & 6 \\
\hline & Tessera 1 & -2 & 3 & 2 & 2.4 & 4.4 & 6 \\
\hline & Tessera 3 & -2 & 3 & 2 & 2.4 & 4.4 & 6 \\
\hline & Torson 1 & 1 & 3 & 2 & 2.4 & 1.4 & 6 \\
\hline & Torson 2 & -20 & 3 & 2 & 2.4 & 21.4 & 6 \\
\hline & Punta Cane 1 & 19 & 3 & 2 & 2.4 & -16.6 & 6 \\
\hline & & & & & & & \\
\hline & AUSTRALIA & & & & & & \\
\hline \multirow[t]{4}{*}{ Saltmarsh } & $\begin{array}{l}\text { Tweed River - } \\
\text { Ukerebagh Island }\end{array}$ & $0.5+/-0.7 \mathrm{~ns}$ & 3 & 3 & -0.4 & -0.4 & 17 \\
\hline & $\begin{array}{l}\text { Hunter River - } \\
\text { Kooragang Island }\end{array}$ & $1.9+/-1.0$ & NA & 3 & 0.3 & -1.6 & 17 \\
\hline & $\begin{array}{l}\text { Parramatta R. - } \\
\text { Homebush Bay } \\
\end{array}$ & $2.9+/-1.6$ & 4 & 3 & 0.9 & -2.0 & 17 \\
\hline & $\begin{array}{l}\text { Jervis Bay - } \\
\text { Currambene Creek }\end{array}$ & $0.1+/-1.5 \mathrm{~ns}$ & 4 & 3 & 4.1 & 4.1 & 17 \\
\hline & & & & & & & \\
\hline
\end{tabular}




\begin{tabular}{|c|c|c|c|c|c|c|c|}
\hline & $\begin{array}{l}\text { Western Port Bay- } \\
\text { French Island }\end{array}$ & $5.3+/-1.0$ & 3 & 3 & 2.7 & -2.6 & 17 \\
\hline & $\begin{array}{l}\text { Western Port Bay - } \\
\text { Kooweerup }\end{array}$ & $-0.2+/-0.9 \mathrm{~ns}$ & 3 & 3 & 2.7 & 2.7 & 17 \\
\hline & $\begin{array}{l}\text { Western Port Bay - } \\
\text { Quail Island }\end{array}$ & $-0.7+/-1.2 \mathrm{~ns}$ & 3 & 3 & 2.7 & 2.7 & 17 \\
\hline & $\begin{array}{l}\text { Western Port Bay - } \\
\text { Rhyll }\end{array}$ & $0.6+/-0.8 \mathrm{~ns}$ & 3 & 3 & 2.7 & 2.7 & 17 \\
\hline & $\begin{array}{l}\text { Brisbane - } \\
\text { Moreton Bay }\end{array}$ & & & & & & \\
\hline & East & 1.7 & 3 & 3 & 2.0 & 0.3 & 14 \\
\hline & West & -0.3 & 3 & 3 & 2.0 & 2.3 & 14 \\
\hline & & & & & & & \\
\hline $\begin{array}{l}\text { FORESTED } \\
\text { WETLAND }\end{array}$ & & & & & & & \\
\hline & UNITED STATES & & & & & & \\
\hline & $\begin{array}{l}\text { Florida - } \\
\text { Rookery Bay, Naples }\end{array}$ & & & & & & \\
\hline & Basin 1 & $3.9+/-0.9$ & NA & 3 & 2.1 & -1.8 & 16 \\
\hline & Basin 3 & $1.1+/-0.9$ & NA & 5 & 2.1 & 1.0 & 16 \\
\hline & Fringe 3 & $0.6+/-1.8 \mathrm{~ns}$ & NA & 5 & 2.1 & 2.1 & 16 \\
\hline & Restored & $9.9+/-0.5$ & NA & 3 & 2.1 & -7.8 & 16 \\
\hline & & & & & & & \\
\hline & BELIZE & & & & & & \\
\hline & Twin Cays & & & & & & \\
\hline & Fringe & $4.1+/-2.2$ & 3.5 & 3 & 1.5 & -2.6 & 15 \\
\hline & Transition & $-1.1+/-1.5 \mathrm{~ns}$ & 3.5 & 3 & 1.5 & 1.5 & 15 \\
\hline & Dwarf & $-3.7+/-1.0$ & 3.5 & 3 & 1.5 & 5.2 & 15 \\
\hline & & & & & & & \\
\hline & MICRONESIA & & & & & & \\
\hline & Kosrae - Yela River & & & & & & \\
\hline & Fringe & $-3.0+/-0.8$ & 3 & 3 & 1.3 & 4.3 & 11 \\
\hline & Riverine & $-2.7+/-0.6$ & 3 & 3 & 1.3 & 4.0 & 11 \\
\hline
\end{tabular}




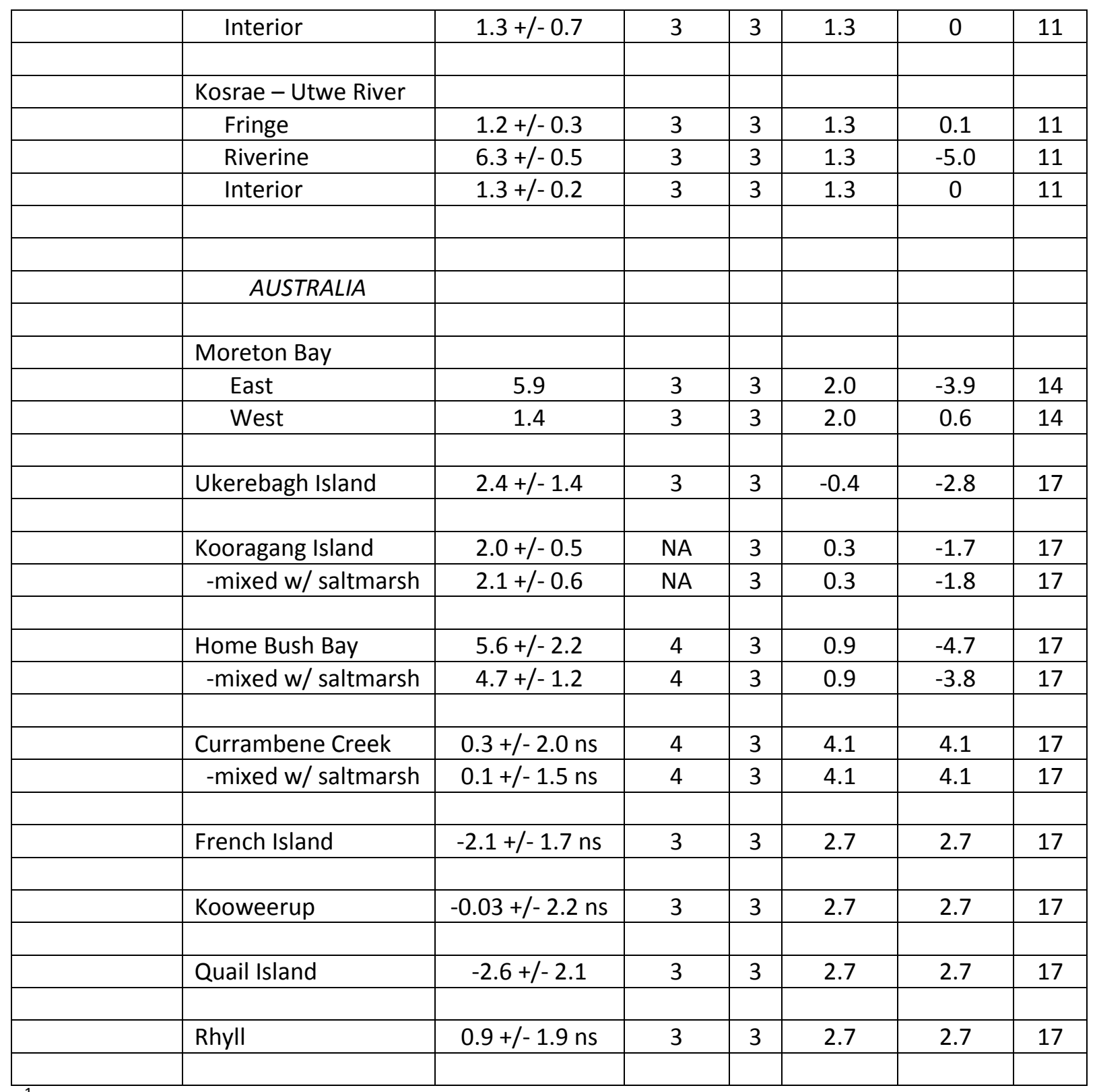

${ }^{1}$ Elevation trends not significantly different from zero are indicated by ns.

${ }^{2} n=$ the number of SET - MH stations at a wetland

${ }^{3}$ When RSLR is presented as a range, the mid-range value was used.

${ }^{4} R S L R_{\text {wet }}$ is calculated as RSLR - VLM

${ }^{5}$ See Supplemental Information for corresponding reference list.

${ }^{6}$ Source $=$ NOAA tide gauge 8577330 at Solomons, Maryland; accessed at <www.tidesandcurrents.noaa.gov> on January 19, 2014. 
${ }^{7}$ Source = NOAA tide gauge 8571892 at Cambridge, Maryland; accessed at $<$ www.tidesandcurrents.noaa.gov> on January 19, 2014.

${ }^{8}$ Source $=$ Cahoon, D., J. Lynch and A. Powell. 1996. Marsh vertical accretion in a southern California estuary. Estuarine Coastal and Shelf Science 43:19-32

${ }^{9}$ Rates were estimated from Figure 6 in Day et al. (1999); reference 6 in Supplemental Information.

Article title: Estimating relative sea-level rise and submergence potential at a coastal wetland

Donald R. Cahoon

US Geological Survey, Patuxent Wildlife Research Center, 10300 Baltimore Avenue, c/o BARC-East, Building 308, Beltsville, MD 20705 USA, email: dcahoon@usgs.gov 